\title{
Body Substance Discharge
}

National Cancer Institute

\section{Source}

National Cancer Institute. Body Substance Discharge. NCI Thesaurus. Code C50437.

The leakage of a substance from an orifice or wound. 